\title{
Otonom Araçlar İçin Optimizasyon Tabanlı Yanal ve Doğrusal Yörünge Planlama
}

\author{
İlhan Mutlu ${ }^{1 *}$ \\ 1* IAV GmbH, Akıllı Sürüş Fonksiyonları Departmanı, Chemnitz, Almanya, (ORCID: 0000-0001-8995-6671), ilhanmutlu86@gmail.com
}

(İlk Geliş Tarihi 5 Mayıs 2021 ve Kabul Tarihi 20 Eylül 2021)

(DOI: 10.31590/ejosat.932390)

ATIF/REFERENCE: Mutlu, İ. (2021). Otonom Araçlar İçin Optimizasyon Tabanlı Yanal ve Doğrusal Yörünge Planlama. Avrupa Bilim ve Teknoloji Dergisi, (27), 539-548.

$\ddot{O} \mathbf{z}$

Son yıllarda, teknolojik gelişmelerin de katkısıyla, otonom araçlar önemli bir ilgi odağı haline gelmiştir. Bu tarz karmaşık sistemlerde istenen performansın elde edilebilmesi için birçok alt problemin etkili bir şekilde çözülmüş olması gerekmektedir. Bu alt problemler detaylı olarak incelendiğinde hareket ve yörünge planlamasının çok önemli ve kritik bir yer tutuğu görülebilir. Bu çalışma kapsamında, yörünge planlama problemi Frenet koordinat düzleminde ele alınmış ve otonom sürüş sistemleri için optimizasyon tabanlı ve etkili bir yörünge planlama yaklaşımı önerilmiştir. Önerilen yöntem temelde bir optimizasyon probleminin analitik çözümünün çevrim dışı aşamada elde edilmesine dayanmaktadır. Böylece, gerçek zamanlı uygulama sırasında ilgili yörünge katsayılarının belirlenmesi için bir doğrusal denklem takımını çözmek yeterli hale gelmektedir. Karşılaşılan pratik sorunlar ve çözüm önerileri de yine bu çalışma kapsamında ele alınmıştır. Önerilen yöntemin etkinliği "Automotive Data and Time-Triggered Framework (ADTF)" ortamında gerçekleştirilen gerçek zamanlı benzetimlerle gösterilmiştir.

Anahtar Kelimeler: Otonom araçlar, otonom sürüş, hareket planlama, yörünge planlama.

\section{Optimization Based Lateral and Longitudinal Trajectory Planning for Autonomous Vehicles}

\begin{abstract}
In recent years, autonomous vehicles have gained significant attention with the help of technological developments. To fulfill the desired performance expectations, various sub-problems have to be solved efficiently in such complex systems. When these subproblems are examined in detail, it can be seen that the motion and trajectory planning play a crucial role. Within the scope of this study, the trajectory planning problem was handled in the Frenet coordinate frame and an efficient optimization-based trajectory planning approach was proposed for autonomous driving. The proposed method was essentially based on the analytical solution of an optimization problem which was derived in the offline phase. In the real-time application, only the corresponding trajectory coefficients should be determined by solving a linear set of equations. Encountered practical problems and solution recommendations were also discussed in this study. The effectiveness of the proposed method was demonstrated via real-time simulations that were realized in the "Automotive Data and Time-Triggered Framework (ADTF)" framework.
\end{abstract}

Keywords: Autonomous vehicles, automated driving, motion planning, trajectory planning.

\footnotetext{
*Sorumlu Yazar: ilhanmutlu86@gmail.com
} 


\section{Giriş}

Günümüzde karayolu taşımacılığı ulaşımda çok önemli bir yer tutmaktadır. Avrupa Birliği verilerine göre 2014 yılında kat edilen toplam mesafenin\%83'ü otomobillerle gerçekleştirilmiştir (Heinrich, 2018). Bu yoğun kullanım karayolundaki güvenliğin arttırılması gereksinimini de beraberinde getirmektedir. Dünya Sağlık Örgütü 2013 yılında karayollarında gerçekleşen kazalarda toplam 1.25 milyon ölüm rapor etmiştir (World Health Organization, 2015). Bu kazaların önemli bir bölümünün insan hatası kaynaklı meydana geldiği düşünülürse karayollarındaki trafiği daha güvenli hale getirecek etkin otonom sürüş ve aktif sürücü destek sistemlerinin geliştirilmesinin ne kadar önemli olduğu ortaya çıkar. Bu nedenle, otonom araçlar son yıllardaki teknolojik gelişmelerin de etkisiyle önemli bir araştırma alanı haline gelişmiştir. İyi tasarlandığında bu tarz sistemlerin insan hayatını kolaylaştırıcı yönde önemli etkilerinin olacağına ve genel güvenlik seviyesini arttırdığına da birçok çalışmada yer verilmiştir (Eugensson ve diğerleri, 2014), (Kalra ve Paddock, 2016).

Yukarıda kısaca bahsedilen avantajlarından dolayı günümüzde birçok üretici, mühendislik firması ve araştırma kuruluşu bu alana yatırım yapmaktadır. Ancak, otonom araçlar ve otonom sürüş sistemleri halen gelişmekte olan ve önemli ölçüde yatırım çeken bir alan olarak kabul edilebilir. Society of Automotive Engineers (SAE)'nin yaptığı sınıflandırmada temel olarak 6 seviye bulunmaktadır. Bu seviyeler, araçta hiçbir sürücü destek sisteminin bulunmadığ 1 ve tüm sorumluluğun her zaman sürücüde olduğu Seviye 0'dan, tam otonomi anlamına gelen ve sürücünün yolu gözlemlemesinin dahi gerekmediği ve aracın kendi sistemleri ile istenen bir noktadan diğerine gitmek için hiçbir sürücü desteğine ihtiyaç duymadığı Seviye 5'e kadar uzanmaktadır (Yiğit ve diğerleri 2020). Günümüzde, ticari açıdan bakıldığında Seviye 2-3 sistemler daha ön planda tutulurken, araştırma projelerinde ise yoğunlukla Seviye 3-5 çözümler üzerine odaklanılmaktadır.

Otonom bir aracın karayolunda güvenli bir şekilde seyredebilmesi için birçok farklı ve detaylı alt problemin etkili bir şekilde çözülmüş olması gerekmektedir (Kuwata ve diğerleri, 2009). Bu problemler; sensör konfigürasyonu ve kurulumundan, algılama algoritmalarının geliştirilmesine, araç hareketinin planlanmasından etkili kontrol yöntemlerinin geliştirilmesine kadar geniş bir aralıkta yer alır. Bu çalışma kapsamında, yanal ve doğrusal yörünge planlama problemi detaylı olarak ele alınmıştır.

Literatürde otonom araçların yol ve yörünge planlaması üzerine yapılmış birçok çalışma mevcuttur (Glaser ve diğerleri, 2010), (Xu ve diğerleri, 2012), (Potzy ve diğerleri, 2019). (González ve diğeleri, 2015) 'de değinildiği gibi bu yaklaşımları, graf arama temelli planlama yöntemleri, örneklem tabanlı yöntemler, eğri interpolasyonu yaklaşımları ve sayısal optimizasyon olarak özetlemek mümkündür. Graf arama temelli yaklaşımlara örnek olarak Dijkstra Algoritması ve temelde bu algoritmaya dayanan $\mathrm{A}^{*}$ yöntemi gösterilebilir. $\mathrm{Bu}$ yaklaşımlar temelde bir grid üzerindeki en kısa yolu bulmayı hedefler ancak bu tarz yaklaşımlarda süreklilik temelli problemlerle karşılaşmak olasıdır. Çözüm sürelerinin uzayabilmesi de gerçek zamanlı uygulama imkânlarını kısıtlayabilen bir diğer unsur olarak karşımıza çıkar. Örneklem tabanlı yaklaşımlara örnek olarak ise "Rapidly-Exploring Random Tree" (RRT) metodu gösterilebilir. $\mathrm{Bu}$ yaklaşım hem global hem de lokal planlama için uygundur e-ISSN: 2148-2683 ve yeterli süre verildiğinde çözüme yakınsamayı vaat eder ancak yine süreklilik ve konfor temelli problemlerle karşılaşılabilir. Eğri interpolasyonu temelli yaklaşımlara ise polinom (Yang ve diğerleri, 2018), Klotoid, Bezier eğrileri (Park, Lee ve Han, 2014), Spline eğrileri temelli birçok yaklaşımı örnek vermek mümkündür. Seçilen eğrinin yapısına bağlı olarak farklı sonuçlar elde etmek mümkün olsa da bu yaklaşımın en temel avantajı düşük hesaplama süreleri iken optimalite temelli sorunlarla karşılaşılabilir. Sayısal optimizasyon temelli yaklaşımlarda ise en genel durumda yol ve araç kısıtlamaları da göz önünde bulundurularak hız, sürüş açısı, doğrusal ve yanal ivme gibi sürüş dinamiklerinin optimizasyonu hedeflenir. Gerçek zamanlı çözüm gerektiren Model Öngörülü Kontrol (Model Predictive Control-MPC) gibi yaklaşımlar özellikle teknolojik gelişmelerin de katkısıyla popülerliğini korumaktadır (Gao, 2014) ve (Weiskircher ve Ayalew, 2015). Ancak gerçeklenebilirlik ve gerekli olan hesaplama yükü bu tarz yaklaşımların karşılaştığı sorunların başında gelmektedir.

$\mathrm{Bu}$ çalışma kapsamında ise özel olarak yörünge planlamasının etkili bir şekilde çözümüne yönelik bir yaklaşım öne sürülmüş ve pratik uygulamalarda karşılaşılan sorunların nasıl çözüldüğü detaylı olarak ele alınmıştır. Doğrusal ve yanal yörünge planlaması problemleri ayrı ayrı optimizasyon problemi olarak formüle edilebilir. Önerilen yöntemde ilgili optimizasyon probleminin analitik çözümü (doğrusal ve yanal yörünge için ayrı ayrı olmak üzere) çevrimdışı evrede elde edilir. Böylece optimal yörüngenin yapısal ifadesi belirlenmiş olur ve bu sayede gerçek zamanlı uygulamada sadece ilgili yörüngenin katsayılarının belirlenmesi yeterli olur. Katsayıların belirlenmesi için ise doğrusal denklem takımının çözülmesi yeterlidir. Bu yaklaşım özellikle gerçek zamanlı uygulamalarda hesaplama yükü açısından büyük bir avantaj sağlamaktadır ve bir çevrimde (ortalama $40 \mathrm{~ms}$ ) çok fazla sayıda yörüngenin hızlıca hesaplanabilmesine ve en iyisinin seçilmesine olarak tanır. Önerilen yöntemin etkinliğinin gerçek zamanlı benzetimler üzerinden gösterilebilmesi adına "Automotive Data and TimeTriggered Framework" (ADTF) ortamında gerekli tüm uygulama modüllerinin entegre edildiği bir "Software In the Loop" (SIL) test ortamı oluşturulmuştur. Gerçek zamanlı benzetimler bu test ortamı üzerinden çalıştırılarak önerilen yörünge planlama yaklaşımın etkinliği gösterilmiştir.

\section{Materyal ve Metot}

\subsection{Otonom Sürüş Mimarisi}

Literatürde otonom sürüş sistemlerinin sınıflandırılmasına yönelik çok sayıda yayın bulunmaktadır. Ancak genel olarak bakıldığında araştırmacılar, bu tarz sistemleri "algıla", "planla" ve "hareket et" prensiplerine dayanan bilişsel sistem (cognitive system) olarak sınıflandırmakta ve çözüm önerileri de yine bu kapsam doğrultusunda öne sürülmektedir (Taş ve diğerleri, 2016). Bahsedilen bu bilişsel sistem mimarisinin ana hatları Şekil 1'de verildiği gibidir. Şekil 1'den de anlaşılabileceği gibi bu tarz bir yaklaşımda öncelikle otonom aracın önündeki yol bilgisi, çevresel faktörler ve sürüş stratejisine etki edebilecek diğer tüm bilgiler sensörler aracılığıyla toplanmalı ve çeşitli bütünleştirme algoritmaları ile anlam bütünlüğü içerecek şekilde işlenmelidir. $\mathrm{Bu}$ aşamada birden fazla sensörün bir niteliği belirlemek için kullanıldığı durumlar mutlaka ayrıntılı olarak ele alınmalıdır. Örneğin kamera, radar ve LIDAR sensörlerinden gelen bilgiler birleştirilerek aracın önündeki bir engelin araca ne kadar uzak olduğu büyük bir hassasiyetle belirlenmelidir. $\mathrm{Bu}$ 
katman kendi içinde sensör seçimi, sensörlerin kurulumu, veri akışının sağlanması ve güvenliği, sensör birleştirmesi (sensor fusion), çevre ve araç modelinin oluşturulması, konumlandırma gibi çok çeşitli ve derin problemleri içerir (Açıkel ve Gökçen, 2019). Sensör verilerinin birleştirilmesinde çoğunlukla Kalman filtresi temelli yaklaşımların kullanıldı̆̆ı söylenebilir.

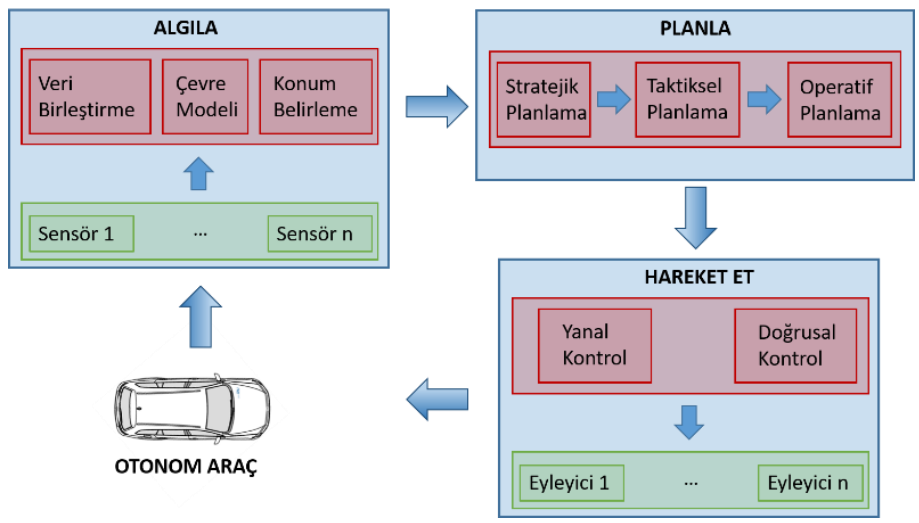

Şekil 1. Bilişsel sistem temelli otonom sürüş mimarisi

$\mathrm{Bu}$ tarz sistemlerdeki bir diğer ana katman ise karar alma/planlama katmanıdır. $\mathrm{Bu}$ katmanın en temel görevi sürülmek istenen rotayı global ve lokal anlamda planlamaktır. $\mathrm{Bu}$ katman da kendi içinde 3 alt katmana ayrılabilir. Bu katmanlar stratejik, taktiksel ve operatif planlama olarak isimlendirilebilir. Stratejik planlama katmanında genellikle rota hesaplamaları gerçekleştirilir. En genel durumda bu katmanda sürücü talepleri ve aracın durumu (örneğin araç bataryasının şarj durumu) göz önünde bulundurularak optimal bir rota hesaplanır. Dolayısıyla bu bölümde alınan kararlar global bir nitelik taşır. $\mathrm{Bu}$ aşamada belirlenen rotanın nasıl gerçekleştirileceği gibi daha somut problemlerle ise taktiksel planlama ve operatif planlama aşamalarında yoğunlaşılır.

Taktiksel planlama aşamasında en genel durumda stratejik aşamada alınan kararların uygulanabilmesi için gerekli olan manevra talepleri oluşturulur. Bu aşamada gerçek sürüş durumu ile hedeflenen durum sürekli olarak karşılıklı olarak kontrol edilir ve gerektiği durumlarda "şeritte kalma", "şerit değiştirme", "park etme" vb. gibi manevra talepleri oluşturularak bir alt katmana iletilir.

Operatif planlama katmanında ise talep edilen manevraların gerçekleştirilebilmesi için gerekli olan yol (path) ve yörünge (trajectory) planlaması gerçekleştirilir. Planlama açısından bakıldığında en alt seviye olarak görülen bu katmanda her bir manevranın durumu ve gerçeklenebilirliği her an kontrol edilir. Yörünge planlaması da bu katmana dahil olduğundan bu çalışma kapsamında bu konudaki detaylara ilerideki bölümlerde ayrıntılı olarak yer verilecektir.

Şekil 1'de gösterilen en son katman ise planlamadan sonra gelen "Hareket Et" katmanıdır. Bu aşamada bir önceki katmanda oluşturulan yanal ve doğrusal yörünge referans olarak kabul edilir ve hem yanal hem de doğrusal hareketin planlanan yörünge çerçevesinde gerçekleştirilebilmesi için çeşitli kontrol yöntemleri uygulanır. Böylece yanal ve doğrusal eyleyiciler vasitasıyla aracın planlanan yörünge dâhilinde hareket etmesi sağlanır. Yanal hareketin planlanan şekilde gerçekleştirilebilmesi için yanal sapma, oryantasyon ve eğrilik değerlerinin düzgün bir şekilde kontrol edilmesi gerekirken doğrusal hareket için ise konum hatas1, hiz ve ivmenin kontrol edilmesi gerekmektedir (Schrödel ve Schwarz, 2019).

\subsection{Lokal Hareket Planlaması Katmanı}

$\mathrm{Bu}$ bölümde yörünge ve yol planlamasını da içinde bulunduran lokal hareket planlaması katmanının detayları üzerinde durulacaktır. Kabaca tarif etmek gerekirse bu katmanın en temel görevi yol durumuna, seçilen manevra türüne ve aracın hızına bağlı olarak otonom aracın önündeki yaklaşık 20-100 m için yol ve yörünge planının oluşturulmasıdır. Bu katmanda her bir manevra türüne karşı düşen yolun ayrı bir modül tarafından hesaplandığı çözüm yöntemleri mevcuttur (Schrödel ve Freese, 2019). Örneğin şerit değiştirme manevrası talebi geldiğinde ilgili otonom aracın kat edeceği yol farklı bir modül tarafından hesaplanırken, şeritte kalma veya park etme manevrası talep edildiğinde bu manevralara karşı düşen yollar ilgili manevra modülleri tarafindan oluşturulur. $\mathrm{Bu}$ noktada unutulmaması gereken bir diğer husus da yol bilgisinin aslında ayrık noktalardan oluştuğudur. Diğer bir deyişle gerçeklenebilirlik ve/veya süreklilik ile ilgili kısıtların sağlanmasından bu modüller sorumlu değildir. Bu kisıtlar önerilen sistem mimarisinde daha sonra gelen yörünge planlama modülü tarafından sağlanmalıdır.

Planlanan ve modifiye edilen (güvenlikle ilgili kısıtlar doğrultusunda) yol bilgisi lokal hareket planlaması katmanında son olarak yörünge planlama modülüne iletilir. $\mathrm{Bu}$ aşamada hedeflenen, gelen yol bilgisi doğrultusunda aracın başlangıç konumundan planlanan son konumuna mümkün olduğunca yumuşak bir yörünge doğrultusunda ilerlemesini sağlayacak yörüngenin hesaplanmasıdır. $\mathrm{Bu}$ kapsamda araç içindeki yolcuların konforu ve güvenliğinin yanı sıra oluşturulan yörüngenin araç tarafindan gerçeklenebilir olup olmadığı da mutlaka göz önünde bulundurulmalıdır.

\section{Araştırma Sonuçları ve Tartışma}

\subsection{Yörünge Planlama}

Önceki bölümde de kısaca değinildiği gibi "yol" aslında otonom aracın ilerisindeki hareket alanının ayrık bir temsilidir. Diğer bir deyişle yol ayrık noktalardan oluşan ve duruma göre hem konum hem de hiz bilgisini de içerebilen bir listedir. $\mathrm{Bu}$ nedenle en genel durumda, araç dinamiklerine ilişkin fizibilite, gerçeklenebilirlik koşulları ve/veya sürüş konforu "yol" tarafından karşılanmaz. Otonom sürüş kapsamında bu kıstaslar yörünge tarafından karşılanmalıdır.

Aracin istenen/planlanan durumu olarak da ifade edilebilen yörünge terimi ise doğrusal ve yanal pozisyonun, hızın ve ivmenin sürekli zamandaki bir ifadesi olarak tanımlanabilir. Bu çalışma kapsamında önerilen yörünge planlama yaklaşımındaki en temel kavramlar, yolun ortasını temsil eden referans eğrisi, doğrusal ve yanal yörünge olduğu iddia edilebilir. Bu nedenle, bu temel kavramlar ve nasıl hesaplandıkları ayrıntılı olarak ele alınacaktır.

\subsubsection{Referans Ĕgrisi}

Şerit temelli koordinat düzlemleri otonom sürüş ile ilgili alanlarda birçok durumun daha etkili temsil edilmesine ve çözüm yollarına daha doğrudan gidilmesine olanak tanır. $\mathrm{Bu}$ nedenle geliştirilen yörünge planlama yaklaşımında Frenet koordinat düzlemi temel alınmıştır. $\mathrm{Bu}$ koordinat düzleminde, referans eğrisi yolun ortasını temsil eder ve eğer bir yanal sapma söz konusu ise en genel durumda amaç bu referans eğrisine yani yolun ortasına yakınsamaktır. 


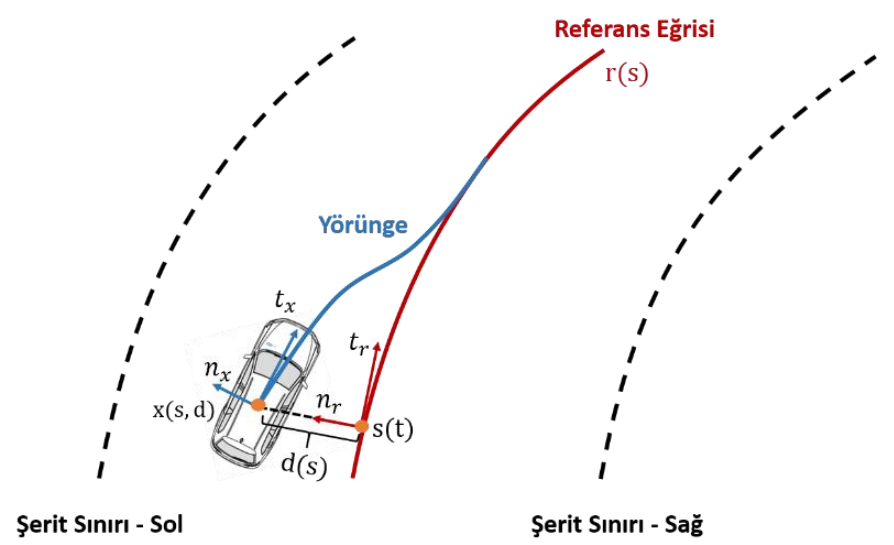

Şekil 2. Frenet koordinat düzlemi ve yörünge

Şekil 2 'den de görülebileceği gibi bu eğrinin teğet ve normal doğrultuları sirasıyla doğrusal $(s(t))$ ve yanal $(d(s))$ yörüngenin doğrultusunu belirlemede kullanılır. $\mathrm{Bu}$ tarz bir yaklaşım hem insan benzeri sürüş dinamiklerini oluşturmayı daha kolay hale getirir hem de farklı ve çok sayıdaki doğrusal ve yanal yörünge çiftlerinin birleştirilmesine olanak tanır (Werling ve diğerleri, 2010). Bu durum da sonuçta istenen performans kriterini optimize eden doğrusal ve yanal yörünge çiftinin seçilebilmesine olanak tanır.

Frenet düzleminde referans eğrisi her şeyin temelidir. Referans eğrisi ve yörünge bilgileri verildiğinde otonom aracın koordinatları doğrudan belirlenebilir. Diğer taraftan aracın konumunun bilindiği ve referans eğrisinin elde edildiği durumlarda, karşı düşen yanal sapmanın ifadesini de belirlemek mümkündür (Nicklas, 2013). Aracın konumu referans eğrisinin normali üzerinde yer almalıdır. Bu nedenle doğrudan analitik bir yaklaşımla referans eğrisinin hangi noktasının bu koşulu sağladığını belirlemek en genel durumda mümkün değildir. Ancak, pratikte Newton yöntemi gibi sayısal yöntemler kullanılarak bu nokta büyük bir hassasiyetle belirlenebilir.

\subsubsection{Doğrusal Yörünge}

Doğrusal yörünge aracın hareket doğrultusundaki konumunun zamana bağlı olarak değişimi olarak tanımlanabilir. Elde edilen doğrusal yörüngenin zamana bağlı türevleri alındığında doğrusal hiz ve ivme profili de kolaylıkla belirlenebilir. Özellikle şehir içindeki trafik koşulları ve değişen hız sınırlamaları göz önünde bulundurulduğunda doğrusal yörüngenin sürüş güvenliğine ve konfora etkisinin çok önemli olduğu kolayla görülebilir.

$\mathrm{Bu}$ çalışma kapsamında otonom aracın kinematik hareket modeli kullanılarak (çift katlı integratörlü sistem) belirli bir performans ölçütünü minimize eden doğrusal yörüngenin analitik çözümü hesaplanmıştır.

İlgili optimal kontrol problemi

$$
\begin{gathered}
\min J_{s}=k_{t_{f}} t_{f}+\int_{0}^{t_{f}} \frac{\alpha_{s}}{2} u_{s}^{2}(t)+\frac{\gamma_{s}}{2} s_{3}^{2}(t) \mathrm{d} t \\
\dot{s}(t)=\left[\begin{array}{lll}
0 & 1 & 0 \\
0 & 0 & 1 \\
0 & 0 & 0
\end{array}\right] s(t)+\left[\begin{array}{l}
0 \\
0 \\
1
\end{array}\right] u_{s}(t), \\
s(0)=s_{0} \text { ve } s\left(t_{f}\right)=s_{t_{f}}
\end{gathered}
$$

şeklinde formüle edilmiştir. Burada $s$ durum vektörünü temsil etmektedir ve $s_{1}, s_{2}$ ve $s_{3}$ sirasıyla kat edilen mesafeyi, hızı ve ivmeyi temsil etmektedir. İvmenin türevi ise giriş işareti olarak kabul edilmiştir. (1)'den görülebileceği gibi performans ölçütü son değer bileşeni dışında $\left(k_{t_{f}} t_{f}\right)$ en temelde ivme ve ivmenin türevine bağlı karesel ifadelere bağlıdır. $\mathrm{Bu}$ durum ise sadece ivmenin türevinin göz önünde bulundurulduğu (Werling ve diğerleri, 2010) ve (Potzy ve diğerleri, 2019) gibi çalışmaların aksine hem yolcu konforunun hem de enerji verimliliğinin birlikte değerlendirilebilmesi açısından avantaj sağlamaktadır.

$\alpha_{s}$ ve $\gamma_{s}$ terimleri ise ağırlık katsayılarıdır. $\mathrm{Bu}$ çalışma kapsamında ivme ve ivmenin türevinin optimal kontrol problemine eşit oranda etki etmesi istendiğinden her iki ağırlık katsayısı da 0.25 olarak seçilmiştir. Bu noktada esas önemli olan ise her iki ağırlık katsayısının birbirlerine olan oranıdır. Örneğin ivme değerinin daha baskın olması istenirse $\gamma_{s} / \alpha_{s}$ oran1 1 'den büyük olacak şekilde ağırlık katsayıları seçilmelidir. (1) ile ifade edilen optimal kontrol probleminde $t_{f}$ son zamanı temsil ederken $k_{t_{f}}$ ise son zamanın etkisini tüm performans ölçütü içerisinde ağırlıklandıran katsayıdır.

Burada amaç (1) ile ifade edilen $J_{S}$ fonksiyonelini minimize eden yörüngenin diğer bir deyişle $s_{1}$ 'in belirlenmesidir. $\mathrm{Bu}$ aşamada analitik çözüm Pontryagin'in Minimum Prensibi yöntemi temel alınarak belirlenebilir. (Mutlu ve diğerleri, 2019)'da belirtildiği gibi karşı düşen Hamiltonian ifadesi

$$
\mathcal{H}\left(t, s^{*}, u_{s}^{*}, \lambda\right)=\lambda_{1} s_{2}+\lambda_{2} s_{3}+\lambda_{3} u_{s}+\frac{\alpha_{s}}{2} u_{s}^{2}+\frac{\gamma_{s}}{2} s_{3}^{2}
$$

şeklindedir. Burada $\lambda_{1}, \lambda_{2}$ ve $\lambda_{3}$ Lagrange çarpanlarını temsil eder. $\mathrm{Bu}$ noktada sonuca Hamiltonian ifadesinin gradyeni alınarak ve sonuçta elde edilen homojen diferansiyel denklem çözülerek gidilebilir (Liberzon, 2011). Bu yöntem izlendiğinde

$$
\frac{\mathrm{d}^{6} s_{1}^{*}}{\mathrm{~d} t^{6}}-\frac{\gamma_{s}}{\alpha_{s}} \frac{\mathrm{d}^{4} s_{1}^{*}}{\mathrm{~d} t^{4}}=0
$$

şeklinde altıncı mertebeden homojen bir diferansiyel denklem elde edilir. Diferansiyel denklemin karakteristik eşitliği ise

$$
p(\xi)=\xi^{6}-\xi^{4} \frac{\gamma_{s}}{\alpha_{s}}=\xi^{4}\left(\xi^{2}-\frac{\gamma_{s}}{\alpha_{s}}\right)
$$

olarak yazılabilir. Bu durumda $\xi=0$ 'da dört katlı kök olduğu ve diğer iki kökün de

$$
\xi_{5}=\sqrt{\frac{\gamma_{s}}{\alpha_{s}}} \text { ve } \xi_{6}=-\sqrt{\frac{\gamma_{s}}{\alpha_{s}}}
$$

şeklinde belirlenebileceği görülür. $\mathrm{Bu}$ durumda (1) ile verilen optimal kontrol problemini minimize eden $s_{1}$ yani doğrusal yörünge analitik olarak

$$
s_{1}(t)=\sigma_{0}+\sigma_{1} t+\sigma_{2} t^{2}+\sigma_{3} t^{3}+\sigma_{4} e^{k_{s} t}+\sigma_{5} e^{-k_{s} t}
$$

olarak belirlenir. Böylece ilgili optimal kontrol problemini minimize eden yörüngenin yapısı belirlenmiş oldu. $\sigma_{0-5}$ katsayı terimlerinin belirlenebilmesi için ise 


$$
\left[\begin{array}{cccccc}
1 & 0 & 0 & 0 & 1 & 1 \\
0 & 1 & 0 & 0 & k_{s} & -k_{s} \\
0 & 0 & 2 & 0 & k_{s}^{2} & k_{s}^{2} \\
1 & t_{f, j}^{i} & t_{f, j}^{i}{ }^{2} & t_{f, j}^{i}{ }^{3} & e^{k_{s} t_{f, j}^{i}} & e^{-k_{s} t_{f, j}^{i}} \\
0 & 1 & 2 t_{f, j}^{i} & 3 t_{f, j}^{i}{ }^{2} & k_{s} e^{k_{s} t_{f, j}^{i}} & -k_{s} e^{-k_{s} t_{f, j}^{i}} \\
0 & 0 & 2 & 6 t_{f, j}^{i} & k_{s}^{2} e^{k_{s} t_{f, j}^{i}} & k_{s}^{2} e^{-k_{s} t_{f, j}^{i}}
\end{array}\right]\left[\begin{array}{c}
\sigma_{0}^{i} \\
\sigma_{1}^{i} \\
\sigma_{2}^{i} \\
\sigma_{3}^{i} \\
\sigma_{4}^{i} \\
\sigma_{5}^{i}
\end{array}\right]=\left[\begin{array}{c}
S_{0} \\
\dot{s}_{0} \\
\ddot{s}_{0} \\
s^{i} \\
\dot{s}^{i} \\
\ddot{s}^{i}
\end{array}\right]
$$

şeklinde formüle edilen doğrusal denklem takımının çözülmesi gerekmektedir. Burada ilk üç satır aracın başlangıçtaki doğrusal konumunu, hızını ve ivmesini temsil ederken son üç satır ise aracın istenen son durumundaki doğrusal pozisyonu, hızı ve ivmeyi temsil etmektedir. İlk üç satırın oluşturulabilmesi için $t=0$ alınmıştır. Örneğin (6) ile ifade edilen doğrusal yörüngede $t=0$ alındığında (7)'de verilen matrisin ilk satırı elde edilir. Aynı şekilde (6)'nın türevi $t=0$ alınarak yeniden yazıldığında ise (7)'nin ikinci satırı elde edilir. 4-6. satırları için ise $t=t_{f}$ alınarak işlemler gerçekleştirilmiştir. Böylece altı bilinmeyene $\left(\sigma_{0-5}\right)$ karşılık altı denklem elde edilmiş olur (3 ilk koşul ve 3 son koşul). Bu sayede gerçek zamanlı uygulamada optimizasyon probleminin tekrar tekrar çözülmesine gerek kalmaz. Verilen bir ilk ve son koşul çifti için optimal yörünge parametreleri lineer denklem takımının çözümünden doğrudan elde edilebilir. Yine bu sayede son koşullar çok fazla sayıda değiştirilerek gerçek zamanlı uygulamada pratik açıdan en uygun yörünge belirlenebilir.

\subsubsection{Yanal Yörünge}

Otonom araç eğer yolun ortasından (bu yaklaşımda referans eğri) sapmış ise nasıl bir yörünge izleyerek referans eğrisine yakınsayacağı yanal yörünge tarafından belirlenir. Diğer bir deyişle yanal yörüngenin en temel görevi meydana gelen yanal sapmaları mümkün olduğunca yumuşak bir yol izleyerek kapatmak ve aracı tekrar yolun ortasında konumlandırmaktır.

Yanal yörüngenin belirlenmesi için de doğrusal yörüngedekine benzer bir yaklaşım kullanılabilir. Bu aşamada aracın yanal hareketi kinematik yaklaşımla modellenecektir. $d$ durum vektörünün elemanları $d_{1}, d_{2}$ ve $d_{3}$ sirasıyla yanal sapma (yanal yörünge), yanal hız ve yanal ivmeyi temsil etmektedir.

Yanal yörüngenin belirlenmesine yönelik olarak

$$
\begin{gathered}
\min J_{d}=k_{t_{f}} t_{f}+\int_{0}^{t_{f}} \frac{\alpha_{d}}{2} u_{s}^{2}(t)+\frac{\gamma_{d}}{2} d_{2}^{2}(t) \mathrm{d} t \\
\dot{d}(s(t))=\left[\begin{array}{lll}
0 & 1 & 0 \\
0 & 0 & 1 \\
0 & 0 & 0
\end{array}\right] d(s(t))+\left[\begin{array}{l}
0 \\
0 \\
1
\end{array}\right] u_{d}(t), \\
d(0)=d_{0} \text { ve } d\left(s\left(t_{f}\right)\right)=d_{s\left(t_{f}\right)}
\end{gathered}
$$

şeklinde formülüze edilen optimal kontrol probleminin çözülmesi gerekmektedir. Bu formülasyonda $u_{d}$ yanal ivmenin türevini temsil ederken, $\alpha_{d}$ ve $\gamma_{d}$ terimleri ise ağırlık katsayılarıdır.

Doğrusal yörüngedekine benzer yöntemler kullanıldığında ise analitik çözüm $k_{d}=\sqrt[4]{\frac{\gamma_{d}}{4 \alpha_{d}}}$ olmak üzere

$$
\begin{array}{r}
d_{1}(s)=\delta_{0}+\delta_{1} s+e^{k_{d} s}\left(\delta_{2} \cos \left(k_{d} s\right)+\delta_{3} \sin \left(k_{d} s\right)\right) \\
+e^{-k_{d} s}\left(\delta_{4} \cos \left(k_{d} s\right)+\delta_{5} \sin \left(k_{d} s\right)\right)
\end{array}
$$

şeklinde belirlenir. Bu çözümde $\delta_{0-5}$ katsayı terimlerini ifade etmektedir ve gerçek zamanlı uygulamada bu katsayı terimleri verilen bir ilk ve son koşul seti için belirlenmelidir. Bu aşamada (9)'un türevi alınarak yanal hız onun da türevi alınarak yanal ivmenin analitik ifadesi belirlenebilir.

$\delta_{0-5}$ 'in belirlenebilmesi için yine toplamda altı adet denkleme ihtiyaç duyulur. Bunlardan 3'ü ilk koşullardan (yanal pozisyon, yanal hız ve yanal ivme) diğer 3 ü ise son koşullardan gelmektedir (yanal son pozisyon, yanal son hiz ve yanal son ivme). Yanal yörünge özelinde konuşulduğunda son hız ve son ivme genellikle sıfır olarak seçilir bunun nedeni araç yolun ortasına ulaştığında hâlihazırdaki hızı ve/veya ivmesiyle yolun diğer tarafina savrulmasını engellemektir (Voßwinkel ve diğerleri, 2020). Bu bilgiler ışığında gerçek zamanlı uygulamada çözülmesi gereken doğrusal denklem takımı

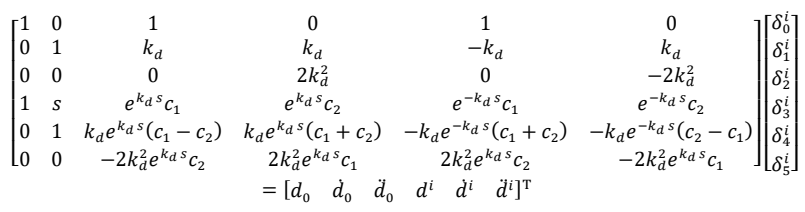

şeklinde ifade edilebilir. Burada $c_{1}$ ve $c_{2}$ sirasiyla $c_{1}=\cos \left(k_{d} s\right)$ ve $c_{2}=\sin \left(k_{d} s\right)$ olarak ifade edilen kisaltmalardır.

\subsection{Yörünge Planlamada Gerçekleştirilen Temel Adımlar}

$\mathrm{Bu}$ bölümde önerilen yörünge planlama yönteminin gerçeklenmesinde takip edilen ana adımlara yer verilecektir. Şekil 3 'ten de görülebileceği gibi öncelikle yol bilgisi kullanılarak referans eğrisi hesaplanır. Ardından doğrusal ve yanal yörünge hesaplamaları ayrı ayrı paralel bir şekilde gerçekleştirilir. Bu aşamada hem doğrusal hem de yanal yörünge için yapılması gereken ilk ve son koşul çiftlerinin belirlenmesidir. İlk koşullar genel olarak ölçüm verisine bağlı olmakla birlikte son koşullar birden fazla olarak belirlenebilir. $\mathrm{Bu}$ sayede yüzlerce doğrusal ve yanal yörünge ayrı ayrı hesaplanmış olur.

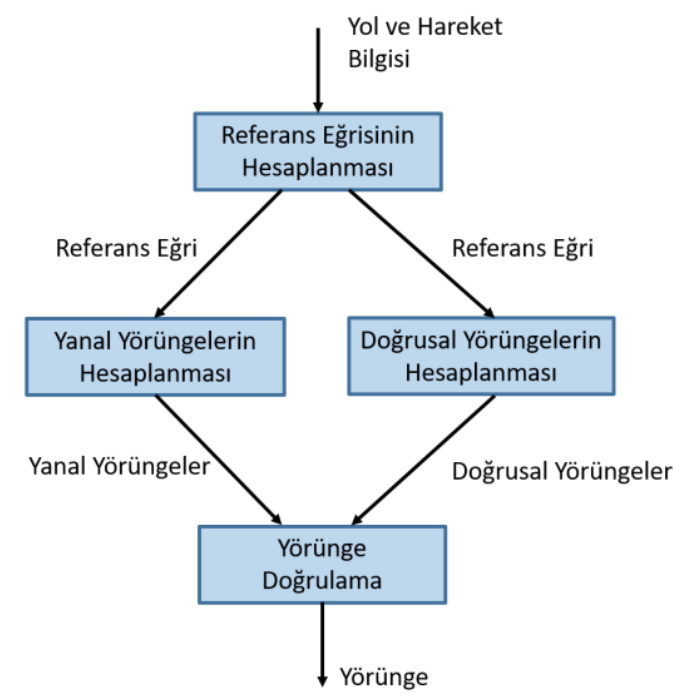

Şekil 3. Yörünge planlamasında uygulanan temel adımlar

Sonuçta istenen ise bir adet doğrusal ve yanal yörünge çiftinin belirlenmesidir. Aslında son olarak belirlenen bu doğrusal ve yanal yörünge çifti bizim için "yörünge" olarak isimlendirilir. 
Diğer bir deyişle eğer 100 adet doğrusal 10 adet de farklı yanal yörünge hesaplandiysa sonuç olarak toplamda 1000 adet yörünge çifti elde edilmiş olur. Bu bin adet yörünge

$$
J(s(t), d(s))=k_{s} J_{s}(s(t))+k_{d} J_{d}(d(s))
$$

kıstasına göre sıralanır ve doğrulama testlerine sokulur. (11) ile ifade edilen ölçütü optimize eden ve tüm doğrulama testlerinden başarı ile geçen yörünge ise "en iyi" olarak belirlenir ve bu yörüngenin katsayıları (hem doğrusal hem de yanal) kontrol katmanına iletilir.

\subsection{Karşılaşılan Pratik Problemler ve Çözüm Önerileri}

Önerilen yörünge planlama yaklaşımı park etme gibi düşük hızlı uygulamalardan otoban sürüşleri gibi yüksek hızlı uygulamalara çok geniş bir alanda uygulanabilirdir. Bununla birlikte yörünge planlama aşamasında kinematik model kullanıldığından araç türünün değişmesi yörünge planlama yaklaşımının her özel durumda yeniden düzenlenmesini gerektirmemektedir. Bu ve bunun gibi birçok avantajın yanı sıra gerçek zamanlı uygulamada göz önünde bulundurulması gereken çeşitli pratik sorunlar da mevcuttur. Bu bölümde yapılan araç testlerinde ve deneme sürüşlerinde karşılaşılan pratik sorunlara ve bu sorunlara karşı önerilen ve geliştirilen çözümlere yer verilecektir.

\subsubsection{Referans Ĕgrisi}

Daha önce de değinildiği gibi otonom aracın ilerisindeki yolun ortasının sürekli zamandaki bir ifadesi olan referans eğrisi önerilen yörünge planlama yaklaşımın en temel bileşenlerinden bir tanesidir. $\mathrm{Bu}$ eğrinin hesaplanabilmesi için temelde bir eğri uydurma yaklaşımına ihtiyaç duyulur. Yapılan ilk uygulamalarda referans eğrisi olarak belirli mertebeden bir polinom hesaplanmıştır. $\mathrm{Bu}$ aşamada hesaplama yöntemi olarak ise en küçük kareler yaklaşımı kullanılmıştır. $\mathrm{Bu}$ yöntemin en temel avantajı kolaylıkla kodlanabilir ve araç üzerinde hızlıca uygulanabilir olmasıdır. Yol profilinin çok fazla değişmediği zamanlarda etkin sonuç almak da mümkün olmuştur. Ancak polinomun yapısal kısıtlarından dolayı sert U-dönüşü gibi bir takım manevraların gerçeklenmesi problematik hale gelmektedir. Polinom mertebesinin arttırılması da bir noktadan sonra polinomun eğriliğini etkilediğinden pratik açıdan burada da bir üst sınır olduğu söylenebilir.

$\mathrm{Bu}$ tarz yapısal sorunların üstesinden gelebilmek adına eğri uydurmanın Bezier Eğrileri kullanılarak gerçekleştirilmesine karar verilmiş̧tir. Bu yaklaşımda aracın ilerisindeki yol belirli alt aralıklara bölünür ve her aralığa ayrı ayrı Bezier eğrileri uydurulur. Yaklaşımın karakteristiği gereği bir birini takip eden eğrilerin geçiş noktalarındaki türevleri de ayarlanabildiğinden eğrilerin sürekliliği de garanti altına alınmış olur. Referans eğrisinin Bezier Eğrileri kullanılarak belirlendiği yaklaşımda eğri uydurma performansının önemli oranda iyileştirildiği gözlemlenmiştir.

\subsubsection{Doğrusal Yörünge}

Doğrusal yörüngenin hesaplama detaylarının ele alındığ önceki bölümlerde de değinildiği gibi ilk ve son koşullar belirlenen doğrusal yörüngenin etkinliği açısından kritik bir öneme sahiptir. İlk koşullar genellikle sensör ölçüm verisi üzerinden gelir ve aracın o anki konum, hız ve ivme bilgisini içerir. Dolayısıyla doğrusal yörünge anlamında ilk koşullara müdahale etmeye en genel durumda gerek yoktur. Ancak istenen son koşullar girdi olarak gelen "yol” profiline bağlıdır.

Şekil 4 'te verildiği gibi bir hız profilinin yörünge planlama modülüne gelen yol bilgisinde yer aldığını düşünelim. Böyle bir durumda otonom aracın ulaşabileceği maksimum hız limitinde sıçrama olduğu açıktır. Önerilen yörünge planlama yaklaşımında eğer doğrudan $\left(s_{3}, v_{3},\right)$ ile belirtilen nokta ulaşılması hedeflenen son nokta olarak seçilse idi bu durumda gelen hız profiline uyma anlamında düşük bir sonuç elde edilmesi mümkündür. Bunun nedeni ise aslında bu senaryoda aracın önce belirli bir ivme ile hızlanıp maksimum hıza (bu özel durumda $v_{\text {maks }}=v_{1}=v_{2}$ ) ulaşmasına ve bir sonraki hız kriterini $\left(v_{3}\right)$ sağlamak için frenleme manevrasına başlamadan önce belirli bir süre bu hızla devam etmesine yetecek kadar mesafe olmasidır.

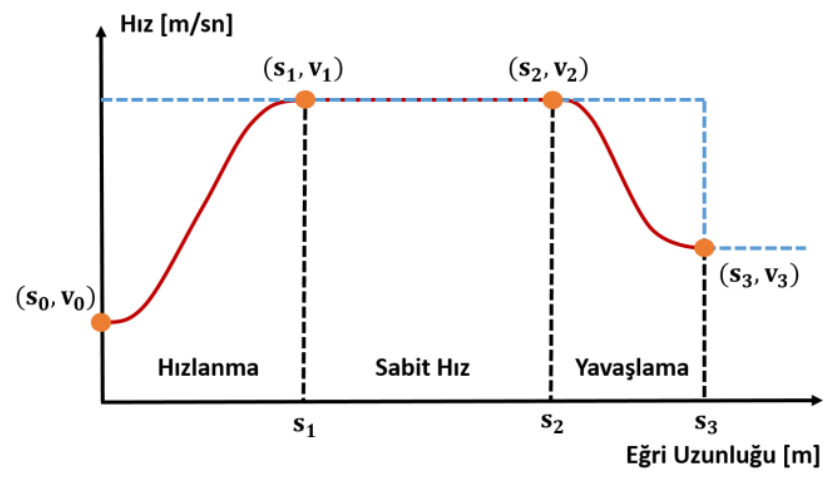

Şekil 4. Örnek bir hız profili

$\mathrm{Bu}$ ve benzeri durumlarda doğrusal yörüngenin etkinliğini arttırabilmek adına planlama modülüne gelen yol profilindeki hız bilgilerinin yapay olarak belirli alt bölgelere ayrıştırılmasına dayanan bir "Hız Profili Ayrıştırma" yaklaşımı önerilmiştir. Bu yöntemde doğrusal yörünge planlama modülüne gelen yolun içerdiği hız profili önceden belirlenen hızlanma ve yavaşlanma ivmeleri kullanılarak belirli alt profillere bölünmektedir. Örneğin Şekil 4 'te son koşul olarak yörünge planlama algoritmasına $\left(s_{3}, v_{3},\right)$ çifti değil $\left(s_{1}, v_{1},\right)$ çifti iletilecektir. Önerilen bu çözüm sayesinde özellikle yol profilinde talep edilen hızların sıklıkla değiştiği durumlarda pratik açıdan önemli iyileştirmeler gözlenmiştir.

\subsubsection{Yanal Yörünge}

Yanal yörünge açısından bakıldığında karşılaşılan pratik problemler genellikle harita ve konumlandırma gereken uygulamalar olmuştur. $\mathrm{Bu}$ tarz uygulamalarda ölçümden ve konumlandırmadan kaynaklı problemlerden dolayı bazı durumlarda bir birini takip eden iki döngü arasında yanal sapma açısından zıplamalar gözlenmiştir. Belirli bir genliğe kadar bu tarz zıplamalar yörünge planlaması açısından problem teşkil etmese de (yanal yörünge hesaplanabilir durumdadır) bu durumun kontrolör katmanına etkileri yolcu konforu açısından olumsuz sonuçlar doğurmaktadır. Bu tarz durumlara çözüm önerisi olarak ise belirli sapmaların tespit edildiği durumlarda bu sapmaları kompanze edebilmek adına ilk koşulların doğrudan ölçüm verileri üzerinden değil aracın önceki konum ve son döngüde kat edilen mesafe üzerinden belirlenmesi yoluna gidilmiştir. 


\subsubsection{Yörünge Doğrulama}

Önerilen yörünge planlama yaklaşımında dinamik sürüș ve gerçeklenebilirlik ile ilgili kısıtlar optimizasyon probleminin içerisinde ele alınmamıştır. $\mathrm{Bu}$ durumun en önemli nedenlerinden biri bu tarz kisitlamalar söz konusu olduğunda analitik çözümü elde etmenin önemli ölçüde zorlaşmasıdır. Bu tarz bir yaklaşımla ilk aşamada dinamik sürüş kısıtları göz önünde bulundurulmadan optimal yörüngelerin (doğrusal ve yanal) yapısı belirlenmiş ve gerçek zamanlı uygulama aşamasında yörünge planlaması doğrusal denklem takımının çözümüne indirgenmiş̧ir. Daha önce de değinildiği gibi bu yöntemle gerçek zamanlı uygulama esnasında bir çevrimde çok fazla sayıda yörüngenin hesaplanması mümkün hale gelmiştir.

Ancak, tasarlanan yörüngelerin uygunluğu ve uygulanabilirliği kontrolör katmanına iletilmeden önce doğrulanmalıdır. Örneğin, eğer hesaplanan yörünge aracın maksimum ivmelenme kapasitesini veya konforlu bir sürüş açısından istenen maksimum ivmelenme değerini aşıyorsa bu yörünge geçersiz olarak işaretlenmeli ve kontrolör katmanına iletilmemelidir.

Bir doğrusal ve bir yanal yörünge son aşamada bir "yörünge" çifti oluşturmaktadır. Geliştirici tarafindan düzenlenebilmekle birlikte önerilen bu yöntemde bir döngüde 1000 'e kadar yörünge çifti hesaplanabilmektedir. Hesaplamalar gerçekleştirildikten sonra hesaplanan yörünge çiftleri (11) ile ifade eden performans ölçütüne göre sıralanır. Tablo 1 'deki tüm koşulları sağlayan ve (11) ile ifade edilen performans ölçütünü minimize eden yörünge çiftine ait katsayılar ise kontrolör katmanına iletilir.

Tablo 1. Uygulanan Doğrulama Testleri

\begin{tabular}{|c|c|}
\hline Doğrulama Testi & Koşul \\
\hline Doğrusal İvme & $a_{x} \leq a_{x, \text { maks }}$ \\
\hline Yanal İvme & $a_{y} \leq a_{y, \text { maks }}$ \\
\hline Kamm's Circle & $a=\sqrt{a_{x}^{2}+a_{y}^{2} \leq a_{m a k s}}$ \\
\hline Eğrilik & $\kappa_{c}=\frac{v_{x} a_{y}-v_{y} a_{x}}{\left(\sqrt{v_{x}^{2}+v_{y}^{2}}\right)^{3}} \leq \kappa_{c, \text { maks }}=\frac{1}{R_{\min }}$ \\
\hline Eğrilik değişimi & $\dot{\kappa}_{c} \leq \kappa_{d, \text { maks }}$ \\
\hline Sürüş yönü & $s_{2}(t) \geq 0, t \in\left[0 t_{\text {son }}\right]$ \\
\hline Şerit içinde kalma & $\begin{array}{l}\text { Planlanan tüm araç konumları } \mathrm{t} \in \\
{\left[0 \mathrm{t}_{\text {son }}\right] \text { için gelen sağ ve sol şerit }} \\
\text { konumlarının arasında kalmalıdır }\end{array}$ \\
\hline
\end{tabular}

Önerilen bu yaklaşım mümkün olduğunca esnek bir yapı sunmaktadır. Örneğin Tablo 1 'de verilen doğrulama testlerinde ele alınan projenin/uygulamanın kapsamına göre kolaylıkla eklemeler yapmak mümkündür.

\subsection{Gerçek Zamanlı Benzetim Sonuçları}

$\mathrm{Bu}$ bölümde, önerilen yörünge planlama yönteminin etkinliği gerçek zamanlı benzetimler üzerinden gösterilecektir. $\mathrm{Bu}$ amaçla hem kontrolör yazılımının hem de planlama modüllerinin bir arada koşturulabileceği "Automotive Data and Time-Triggered Framework" (ADTF) kullanılacaktır. ADTF platformu yapisı itibariyle hem bu tarz benzetimlerin hem de deneysel çalışmaların gerçekleştirilebilmesine olanak sağlayan güçlü bir platformdur. Bu çalışma kapsamında önerilen planlama modülleri doğrudan $\mathrm{C}++$ dilinde gerçeklenmiştir. Kontrolörler ise ilk aşamada Matlab Simulink ortamında gerçeklendikten sonra otomatik kod dönüştürücüler yardımıyla ilgili kontrolörlere karşı düşen ADTF modülleri oluşturulmuştur. Bunun ardından tüm planlama ve kontrol modülleri ATDF ortamında bir konfigürasyon kapsamında birleştirilmiş ve böylece kapalı çevrim benzetimlerin gerçekleştirilebilmesine olanak sağlayan bir test ortamı oluşturulmuştur.

Doğrusal ve yanal yörüngelerin etkinliğinin gösterilebilmesi için Şekil 5 'te gösterildiği gibi bir yol seçilmiştir. Seçilen yol iki adet 100 metrelik düz yol bölümünden ve iki adet de -0.1 eğrilikli virajdan oluşmaktadır. Yolun toplam eğri uzunluğu ise yaklaşık olarak 290 m'dir.

Daha önceki bölümlerde değinildiği gibi yörünge planlamasının ilk adımı referans eğrisinin mümkün olduğunca hassas olarak belirlenmesidir. Bu işlem aracın hareketi boyunca devam eder yani sürekli olarak aracın önündeki belirli bir eğri uzunluğu için referans eğrisi hesaplanır. $\mathrm{Bu}$ amaçla önerilen yöntemde iki farklı seçenek mevcuttur. Bunlardan ilki polinom uydurma, diğeri de Bezier eğrisi uydurmadır. Bu iki yöntemi daha sağlıklı bir şekilde kıyaslayabilmek adına hem düz bir yol bölümünün hem de viraj bölgesini içeren bir yol aralığı ele alınacaktır. Aracın $x=85 \mathrm{~m}$ konumunda bulunduğu durum için hesaplanan referans eğrileri Şekil 6'da verildiği gibidir.
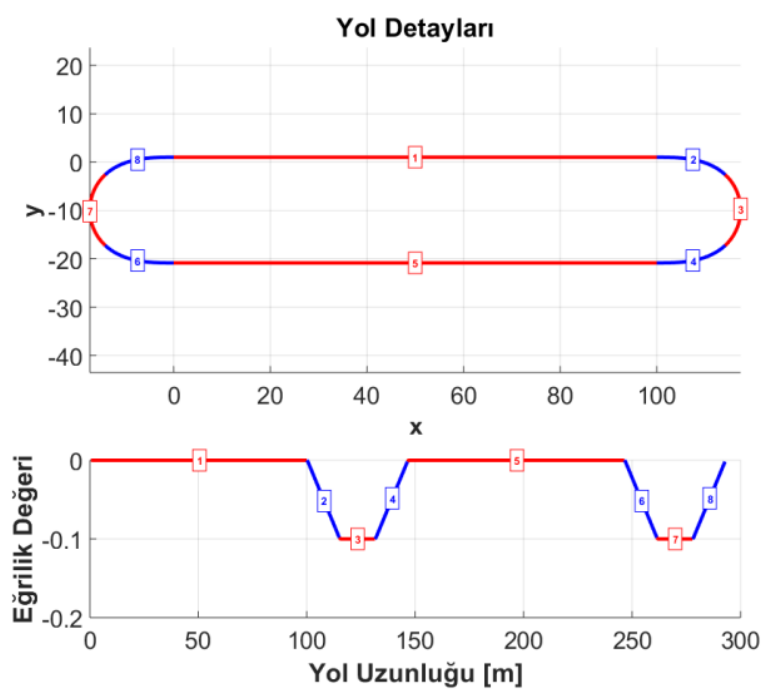

Şekil 5. Benzetimlerde kullanılacak yol profilinin detayları

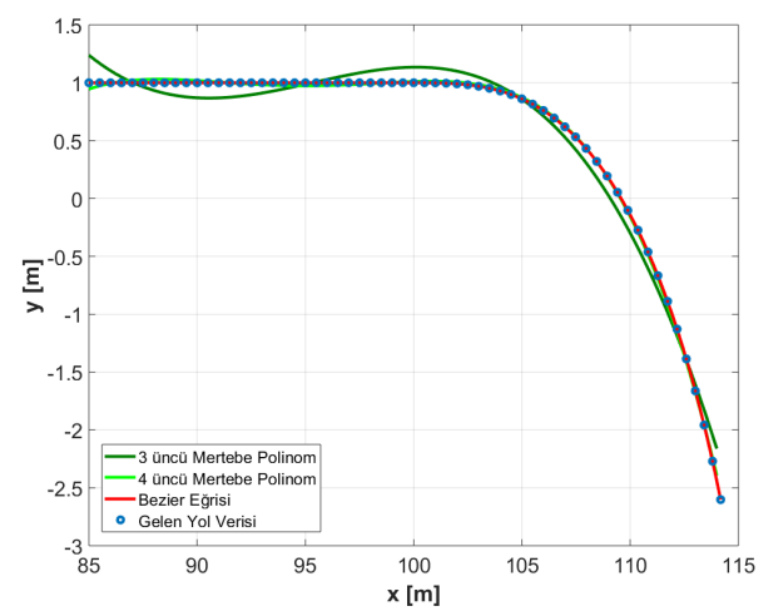

Şekil 6. İlgili yol bölümü için hesaplanan farklı referans eğrileri 
$\mathrm{Bu}$ şekilden de görülebileceği gibi polinom mertebesinin 3 olarak seçildiği durumda eğri istenen noktalara yeterince iyi uydurulamamaktadır. Buna ek olarak bu durumda bir takım yanal kaymalar da söz konusu olur. Diğer taraftan 4. mertebeden polinomla bu durumda iyi bir yaklaşım elde edilmiştir. Polinomun mertebesini arttırmak ilk bakışta daha iyi eğri uydurma sonuçları verecek gibi görünse de pratikte bir takım başka sorunlar doğurmaktadır. Bu sorunların başında küçük de olsa yanal dalgalanmaların artması ve karşılaşılabilecek sayısal sorunlar gösterilebilir. Diğer taraftan Bezier eğrileri ise hem eğri uydurma kalitesi bakımından hem de yanal sapmaları azaltması bakımından daha iyi bir sonuç vermiştir. Bunlara ek olarak, Bezier eğrilerinin sensör gürültülerinin olduğu durumlarda dahi yeterli sonuçlar verdiği gözlemlenmiştir.

Şekil 5 incelendiğinde başlangıç noktasının koordinatlarının $x=0$ ve $y=1$ olduğu görülür. Ego-araç merkezli yaklaşımlarda otonom araç her zaman için koordinat düzleminin merkezinde olduğundan bu durum başlangıçta yanal olarak 1 metrelik farkla neden olur. Seçilen yol profili nedeniyle başlangıçta var olan bu 1 metrelik sapma yanal yörünge aracılığıyla yok edilmelidir. Diğer taraftan aynı zamanda istenen hız profili de doğrusal yörünge aracılığıyla sağlanmalıdır. Başlangıçta araç hızının sıfır olduğu durumda hesaplanan doğrusal ve yanal yörüngeler Şekil 7 ve Şekil 8 'de verildiği gibidir.

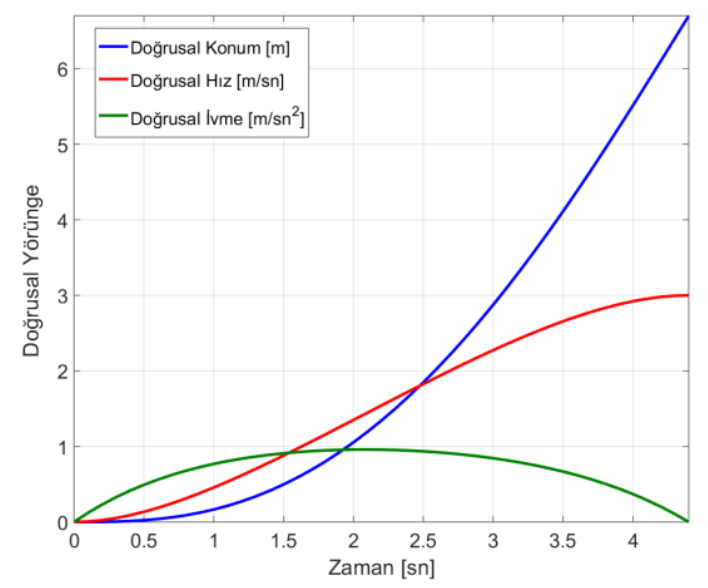

Şekil 7. Başlangıç konumu için hesaplanan doğrusal yörünge

Şekil 7 'den görülebileceği gibi planlanan yörünge aracın ilk hızı olan $v_{i l k}=0 \mathrm{~m} / \mathrm{sn}$ 'den planlanan son hız olan $v_{\text {son }}=$ $3 \mathrm{~m} / \mathrm{sn}$ 'ye ulaşması için yumuşak bir ivmelenme eğrisi içermektedir. Aracın hız ve ivme kontrolünün istenen kriterler dâhilinde performans gösterebilmesi açısından planlama katmanından gelen referans değerlerin mümkün olduğunca düzgün ve sürekli olması büyük önem taşımaktadır. Şekil 7 'den görülebileceği gibi planlama katmanı tarafından üretilen doğrusal yörüngeler kontrol katmanının işini kolaylaştıracak niteliktedir.

Diğer taraftan başlangıçta var olan 1 metrelik yanal sapmanın da yine mümkün olduğunca yumuşak bir şekilde sıfırlanması gerekmektedir. Şekil 8 ile verilen yanal yörünge eğrileri incelendiğinde referans eğrisine olan yanal sapmanın yüksek ve hızlı değişen yanal ivmelere yol açmadan yaklaşık olarak $20 \mathrm{~m}$ içerisinde ortadan kaldırılmasının planlandığ görülmektedir. Sadece yörünge planlaması açısından bakıldığında başlangıçta var olan sapmayı daha kısa mesafede ortadan kaldıran yörüngeleri belirlemek de mümkündür. Ancak e-ISSN: 2148-2683 bu tarz parametre seçimleri kontrolör tarafına binen yükü arttırmakta ve sonuçta elde edilen araç hareketinde istenmeyen sonuçlara da neden olabilmektedir. $\mathrm{Bu}$ nedenle kontrolör tarafındaki kısıtlar ve eğer varsa otonom aracın eyleyici kısıtlamalarını da bu aşamada göz önünde bulundurmak elde edilecek son sonuç açısından bakıldığında mantıklıdır.

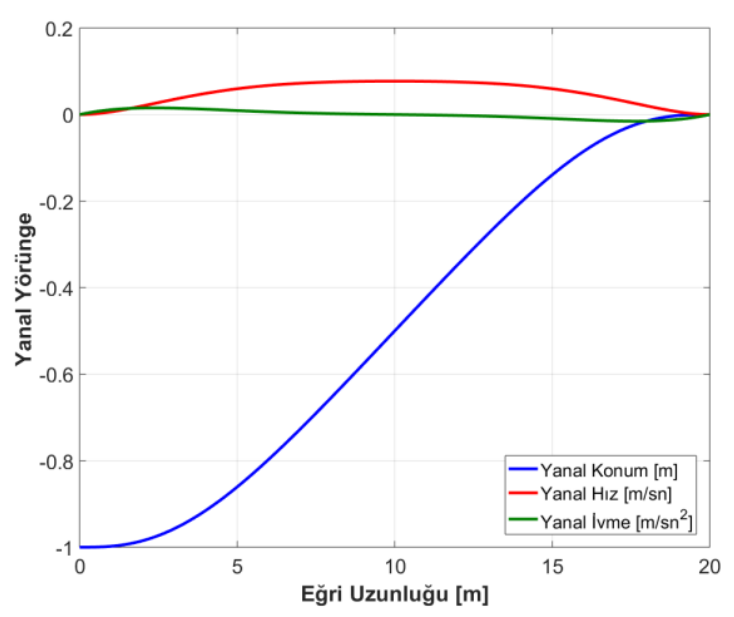

Şekil 8. Başlangıç konumu için hesaplanan yanal yörünge

Ele alınan bu ilk durum başlangıçta hesaplanan yörüngeleri temsil etmektedir. Her çevrimde referans eğrisi, doğrusal ve yanal yörüngeler yeniden hesaplanır. Bunun en temel nedeni ise çevresel faktörlerde, sürüş şeridinde, yol durumunda ve trafikte meydana gelebilecek değişikliklere anında tepki verebilmektir. Ancak özellikle sensör gürültüsü durumunda kontrolöre sürekli tutarsız sinyaller göndermek de uygulama açışından mantıklı değildir. $\mathrm{Bu}$ nedenle eğer bir önceki çevrimde hesaplanan yörünge halen uygulanabilir durumda ise ilgili yörüngenin güncellenerek (hareket verileri de göz önünde bulundurularak) kontrolöre güncellenmiş verilerin gönderilmesi pratik açıdan olumlu sonuçlar doğurmaktadır.

Aracın tüm hareketi boyunca meydana gelen yanal sapma değerleri de Şekil 9 'da verildiği gibi gerçekleşmiştir. Beklenildiği gibi ilk hata değerinin $(1 \mathrm{~m})$ hızlıca kapandığ gözlenmektedir. Planlanan yanal yörüngede aşım olmamasına rağmen gerçekleşen sistem cevabında küçük bir aşım değerinden söz etmek mümkündür. Bu durumun ortadan kaldırılabilmesi için kontrolör katsayılarının daha iyi sonuçlar verecek şekilde ayarlanması ve/veya farklı kontrol yöntemlerine geçilmesi söz konusu olabilir. Bunun dişında otonom araç ilk virajdan geçerken gerçekleşen maksimum sapmanın $0.15 \mathrm{~m}$ civarında olduğu gözlenmiştir. Aracın hızı ve virajın yapısı da göz önünde bulundurulduğunda gerçekleşen yanal kaymanın kabul edilebilir sınırlar içerisinde kaldığı söylenebilir. Benzer bir durum ikinci viraj için de gerçekleşmiştir. Aracın hareketi tam olarak ikinci virajın sonunda sonlandırıldığından son durumda bir miktar yanal kayma görülmektedir. Ancak araç ilk virajdan sonra olduğu gibi hareketine devam etseydi bu sapmanın da hızlıca kapanacağı söylenebilir. 


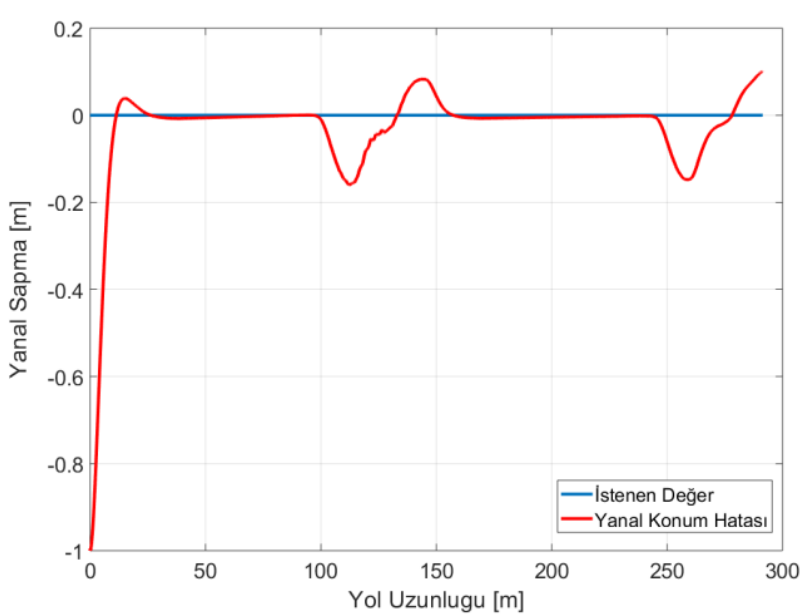

Şekil 9. Tüm yol boyunca gerçekleşen yanal sapma

Bunlara ek olarak otonom aracın tüm yol boyunca gelen hız taleplerini de karşılaması gerekir. Yol boyunca doğrusal yörünge planlama modülüne gelen hız talepleri, bu talepler doğrultusunda planlanan hızlar ve araç tarafından gerçekleştirilen hız grafiklerinin tamamı Şekil 10 'da verildiği gibidir.

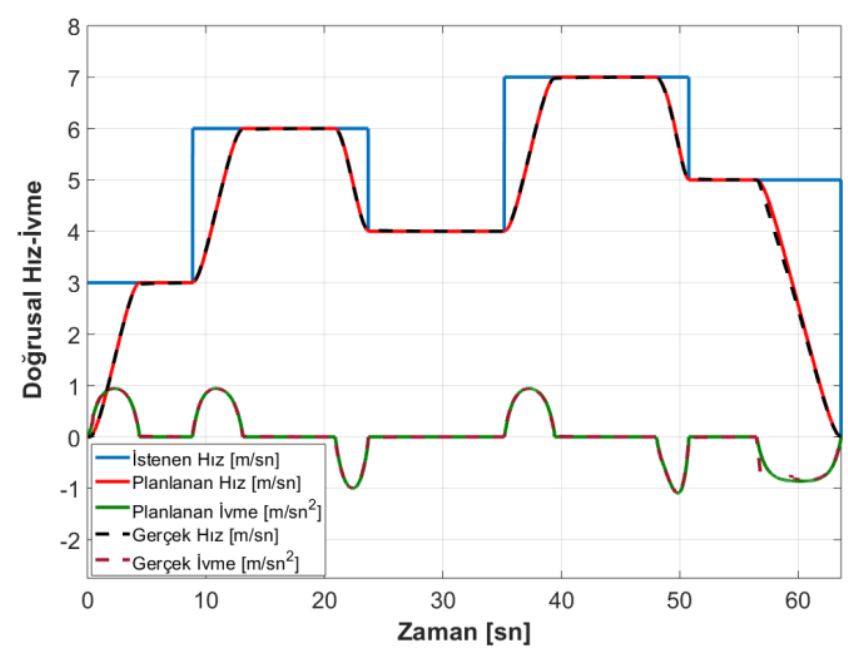

Şekil 10. Tüm yol boyunca gelen hız istekleri, planlanan ve gerçekleşen hızlar

Şekil 10 detaylı olarak incelendiğinde iki temel sonuç dikkat çekmektedir. Bunlardan ilki doğrusal yörünge planlama modülüne gelen hız isteklerinin mümkün olduğunca iyi bir şekilde karşılandığıdır. Görüldüğü gibi istenen hız değerleri toplam yol boyunca 5 faklı değer almıştır. Planlanan hızlar ise bu hızlara mümkün olduğunca yakındır. $\mathrm{Bu}$ durumun gerçekleşmesinde önerilen yörünge planlama yaklaşımına ek olarak daha önceki bölümlerde değinilen "Hız Profili Ayrıştırma" metodunun uygulanmasının da etkili olduğu söylenebilir. Şekil 10 'dan çıkartılabilecek bir diğer sonuç ise planlanan hız ile gerçekleşen hızın çok yakın seyrettiğidir. Doğrusal hareket anlamında planlama katmanı ile kontrolör katmanın büyük bir uyum içerisinde hareket ettiği söylenebilir. $\mathrm{Bu}$ noktada tek istisna ise sondaki durma manevrasıdır. $\mathrm{Bu}$ aşamada kontrolör tarafındaki bazı alt rutinler durma noktasının öncesinde durmayı garanti edebilmek adına ilk aşamada planlanandan fazla bir yavaşlama ivmesi uygulamaktadır.

\section{Sonuç}

$\mathrm{Bu}$ çalışma kapsamında otonom araçlarda yörünge planlaması problemi detaylı olarak ele alınmış ve gerçek zamanlı uygulamalarda kullanılabilecek bir çözüm yöntemi önerilmiştir. $\mathrm{Bu}$ kapsamda önerilen yaklaşım en temelde doğrusal ve yanal hareket için belirlenen optimizasyon problemlerinin analitik çözümlerine dayanmaktadır. Analitik çözümlerin elde edilmesiyle birlikte optimal yörüngelerin yapısı belirlenmiş olur. $\mathrm{Bu}$ yöntemde gerçek zamanlı uygulama esnasında optimizasyon probleminin tekrar çözülmesine gerek duyulmadığından bir çevrimde çok fazla sayıda yörünge hızlıca hesaplanabilmektedir. Diğer bir ifade ile gerçek zamanlı uygulamada yapılması gereken sadece ilgili ilk ve son koşullar için doğrusal denklem takımını çözmek ve yörünge katsayılarını belirlemektir.

$\mathrm{Bu}$ tarz karmaşık problemlerde detaylara inildiğinde genellikle birçok farklı problemle karşılaşılır. Yine bu çalışma kapsamında özellikle yörünge planlaması katmanında karşılaşılan pratik problemler ve çözüm önerileri üzerinde detaylı olarak durulmuştur. Yörünge planlama problemi Frenet düzleminde ele alındığından referans eğrisinin yüksek hassasiyetle belirlenmesi büyük önem taşımaktadır. Bu noktada Bezier eğrilerinin polinomlarda karşılaşılan bir takım yapısal problemlere çözüm olabileceği gösterilmiştir. Buna ek olarak, doğrusal yörünge performansını iyileştirebilmek adına gelen yol bilgisinin bir ön işlemden geçirilmesine dayanan "Hız Profili Ayrıştırma" yaklaşımı önerilmiştir.

Önerilen yörünge planlama yaklaşımın etkinliğini gösterebilmek adına ADTF ortamında gerçek zamanlı benzetimler gerçekleştirilmiştir. Başlangıçta var olan yanal sapmanın planlanan yörünge ile hızlıca ortadan kaldırıldığ gösterilmiştir. Doğrusal hareket açısından bakıldığında ise planlama modülünden talep edilen hızlarda sıçramalar olmasına rağmen hem hızların hem de ilgili ivmelenme ve yavaşlamaların mümkün olduğunca yumuşak bir şekilde planlandığı gösterilmiştir. $\mathrm{Bu}$ nedenle önerilen yörünge planlama yaklaşımının hem şehir içi uygulamalara hem de şehirlerarası sürüş senaryolarına uygun olduğu söylenebilir.

Elde edilen performansın daha ileriye götürebilmesi adına iki temel doğrultuda araştırmalara devam edilmesi planlanmaktadır. Bunlardan ilki yanal hareketin daha da iyileştirilmesi adına özellikle kontrolör tarafında farklı yöntemlerin önerilmesidir. $\mathrm{Bu}$ noktada dayanıklı kontrol yöntemleri ve model öngörülü yaklaşımların üzerinde yoğunlaşılacaktır. Bir diğer araştırma doğrultusu ise yörünge planlama modülündeki parametrelerin akıllı yaklaşımlar kullanılarak daha iyi sistem sonuçları verecek doğrultuda otomatik olarak ayarlanmasıdır.

\section{Kaynakça}

Açıkel, S., \& Gökçen, A. (2019). Localization and point cloud based 3d mapping with autonomous robots. Avrupa Bilim ve Teknoloji Dergisi, (Special Issue), 82-92.

Eugensson, A., Brännström, M., Frasher, D., Rothoff, M., Solyom, S., \& Robertsson, A. (2013). Environmental, safety legal and societal implications of autonomous driving systems. In International Technical Conference on the Enhanced Safety of Vehicles (ESV). Seoul, South Korea (Vol. 334). 
Gao, Y. (2014). Model predictive control for autonomous and semiautonomous vehicles. University of California, Berkeley (Doctoral dissertation).

Glaser, S., Vanholme, B., Mammar, S., Gruyer, D., \& Nouveliere, L. (2010). Maneuver-based trajectory planning for highly autonomous vehicles on real road with traffic and driver interaction. IEEE Transactions on intelligent transportation systems, 11(3), 589-606.

González, D., Pérez, J., Milanés, V., \& Nashashibi, F. (2015). A review of motion planning techniques for automated vehicles. IEEE Transactions on Intelligent Transportation Systems, 17(4), 1135-1145.

Heinrich, S. (2018). Planning universal on-road driving strategies for automated vehicles (Vol. 119). Springer.

Kalra, N., \& Paddock, S. M. (2016). Driving to safety: How many miles of driving would it take to demonstrate autonomous vehicle reliability?. Transportation Research Part A: Policy and Practice, 94, 182-193.

Kuwata, Y., Teo, J., Fiore, G., Karaman, S., Frazzoli, E., \& How, J. P. (2009). Real-time motion planning with applications to autonomous urban driving. IEEE Transactions on control systems technology, 17(5), 1105-1118.

Liberzon, D. (2011). Calculus of variations and optimal control theory. Princeton university press.

Mutlu, İ., Freese, M., Alaa, K., \& Schrödel, F. (2019). Case Study on Model Free Determination of Optimal Trajectories in Highly Automated Driving. IFAC-PapersOnLine, 52(5), 205-211.

Nicklas, M. (2013). Entwicklung eines Trajektorienplaners zum hochautomatischen Fahren im dynamischen Verkehrsumfeld. Technische Universitat Chemnitz, Fakultat für Mathematik.

Park, B., Lee, Y. C., \& Han, W. Y. (2014). Trajectory generation method using Bézier spiral curves for high-speed on-road autonomous vehicles. In 2014 IEEE International Conference on Automation Science and Engineering (CASE) (pp. 927-932). IEEE.

Potzy, J., Goerigk, N., Heil, T., Fassbender, D., \& Siedersberger, K. H. (2019). Trajectory Planning for Automated Merging on Highways. In VEHITS (pp. 283-290).

Schrödel, F., \& Freese, M. (2019). Concept and validation of a guidance approach for highly automated shuttles. IFACPapersOnLine, 52(5), 359-365.

Schrödel, F., \& Schwarz, N. (2019). Case Study on a Proven Concept for Lateral Path Following Control. IFACPapersOnLine, 52(8), 344-349.

Taş, Ö. Ş., Kuhnt, F., Zöllner, J. M., \& Stiller, C. (2016). Functional system architectures towards fully automated driving. In 2016 IEEE Intelligent vehicles symposium (IV) (pp. 304-309). IEEE.

Voßwinkel, R., Mutlu, İ., Alaa, K., \& Schrödel, F. (2020, May). A modular and model-free trajectory planning strategy for automated driving. In 2020 European Control Conference (ECC) (pp. 1186-1191). IEEE.

Weiskircher, T., \& Ayalew, B. (2015). Predictive adas: A predictive trajectory guidance scheme for advanced driver assistance in public traffic. In 2015 European Control Conference (ECC) (pp. 3402-3407). IEEE.

Werling, M., Ziegler, J., Kammel, S., \& Thrun, S. (2010). Optimal trajectory generation for dynamic street scenarios in a frenet frame. In 2010 IEEE International Conference on Robotics and Automation (pp. 987-993). IEEE.

World Health Organization. (2015). Global status report on road safety 2015. World Health Organization.
Xu, W., Wei, J., Dolan, J. M., Zhao, H., \& Zha, H. (2012). A real-time motion planner with trajectory optimization for autonomous vehicles. In 2012 IEEE International Conference on Robotics and Automation (pp. 2061-2067). IEEE.

Yang, D., Zheng, S., Wen, C., Jin, P. J., \& Ran, B. (2018). A dynamic lane-changing trajectory planning model for automated vehicles. Transportation Research Part C: Emerging Technologies, 95, 228-247.

Yiğit, E., ONER, A. E., \& Yöntem, O. (2020). Otonom Araçların Otomotiv Sektörüne Etkileri ve Beraberinde Getirdiği Yenilikler. Avrupa Bilim ve Teknoloji Dergisi, 181-186. 